\title{
Vertical distribution and settling of spring phytoplankton in the offshore NW Baltic Sea proper
}

\author{
Helena Höglander, Ulf Larsson*, Susanna Hajdu \\ Department of Systems Ecology, Marine and Brackish Water Ecology, Stockholm University, Svante Arrhenius väg 21 A, \\ 10691 Stockholm, Sweden
}

\begin{abstract}
We studied the vertical distribution and settling of dominant diatoms and dinoflagellates during the 1996 spring phytoplankton bloom in the offshore NW Baltic Sea proper. We sampled phytoplankton at 11 depths (to $80 \mathrm{~m}$ ) and collected settling cells in sediment traps at 25, 50 and $100 \mathrm{~m}$ depth, every week from March 26 to May 7. Phytoplankton were counted and sized from both water and trap samples, to estimate the share of phytoplankton in bulk settling carbon. Diatoms, mainly Chaetoceros spp. and Achnanthes taeniata, dominated the early bloom, but were replaced by the dinoflagellates cf. Scrippsiella hangoei and Peridiniella catenata when inorganic nitrogen was depleted above the seasonal pycnocline at ca. $10 \mathrm{~m}$ depth. By late April, vertically migrating dinoflagellates had depleted inorganic nitrogen down to $30 \mathrm{~m}$, well below the seasonal pycnocline. We found clear species-specific sedimentation patterns. Scrippsiella hangoei and Chaetoceros spp., which dominated in the water column, were clearly underrepresented in the traps, while Thalassiosira baltica and T. levanderi, which were sparse in the water column, were overrepresented in sediment traps. Only 4, 3 and $0.5 \mathrm{~g} \mathrm{C} \mathrm{m}^{-2}$ (or 16, 12 and $2 \%$ of phytoplankton primary production) settled as intact phytoplankton cells at 25,50 and $100 \mathrm{~m}$, respectively, although these numbers may be overestimated due to migrating $P$. catenata. The settling bulk carbon was $\sim 3 \mathrm{~g} \mathrm{C} \mathrm{m}^{-2}$ or $12 \%$ of the primary production at all depths. This is low compared to other estimates from coastal waters and suggests additional loss mechanisms, e.g. disintegration in the water column and grazing by zooplankton overwintering in the permanent halocline area.
\end{abstract}

KEY WORDS: Phytoplankton $\cdot$ Spring bloom $\cdot$ Sedimentation $\cdot$ Diatoms $\cdot$ Dinoflagellates $\cdot$ Vertical distribution · Baltic Sea

Resale or republication not permitted without written consent of the publisher

\section{INTRODUCTION}

Spring blooms are conspicuous events in temperate waters. In a few weeks, most of the easily available inorganic nutrients in the upper water column are consumed and the phytoplankton biomass produced disappears almost as quickly as it appeared. Due to the low biomass of zooplankton in spring and, therefore, low grazing pressure (von Bodungen et al. 1981, Kuparinen et al. 1984, Larsson et al. 1986b), sedimentation is thought to be the predominant loss process of spring blooms (Reynolds \& Wiseman 1982, Riebesell 1989). This flux of newly produced phytoplankton cells to the sediments is considered the main supply of food to the benthic system in the Baltic Sea (Elmgren 1978). Due to species-specific sedimentation (Passow 1991a, Heiskanen 1998, Tallberg \& Heiskanen 1998), the species composition of the spring phytoplankton bloom influences both the quantity and quality of material settling to the benthos (Passow 1991a, Heiskanen \& Kononen 1994, Olli \& Heiskanen 1999). Rapidly settling diatoms can reach the sediment relatively intact (Davies \& Payne 1984) and are, therefore, high quality food for benthic deposit feeders (Òlafsson \& Elmgren 1997, Lehtonen \& Andersin 1998). With the exception of settling resting cysts (Heiskanen 1993), dinoflagel- 
lates seem instead to disintegrate in the water column and settle as unidentifiable detritus (Heiskanen \& Kononen 1994, Olli \& Heiskanen 1999), or be retained as suspended particles or dissolved organic matter in the water column (Heiskanen 1998). Whether diatoms or dinoflagellates dominate the spring bloom may thus greately influence the input of carbon to the deep water.

In the Baltic Sea, most studies of particle settling are from coastal areas (e.g. Smetacek et al. 1978, Smetacek 1980, Forsskåhl et al. 1982, Larsson et al. 1986b, Heiskanen \& Kononen 1994), where resuspended particulate material may bias estimates of flux as well as of composition of settled material (Blomqvist \& Larsson 1994). In the offshore Baltic Sea, flux estimates are less likely to be influenced by resuspension, but since few studies are available (Leppänen 1988, Leppänen \& Kononen 1988, Passow 1991a, Struck et al. 2004), our understanding of the settling dynamics is limited (Blomqvist \& Heiskanen 2001).

Use of particulate organic carbon (POC) and nitrogen (PON) for measurements of bulk settling material (e.g. Leppänen 1988) mean that both detritus and resuspended material will be included in the flux estimates (Horn \& Horn 1993). By combining these measurements with microscope identification, and counting of phytoplankton cells in water column samples and sediment trap material, it is possible to estimate the amount of settled newly produced material (Horn \& Horn 1993). It is also possible to identify whether car-

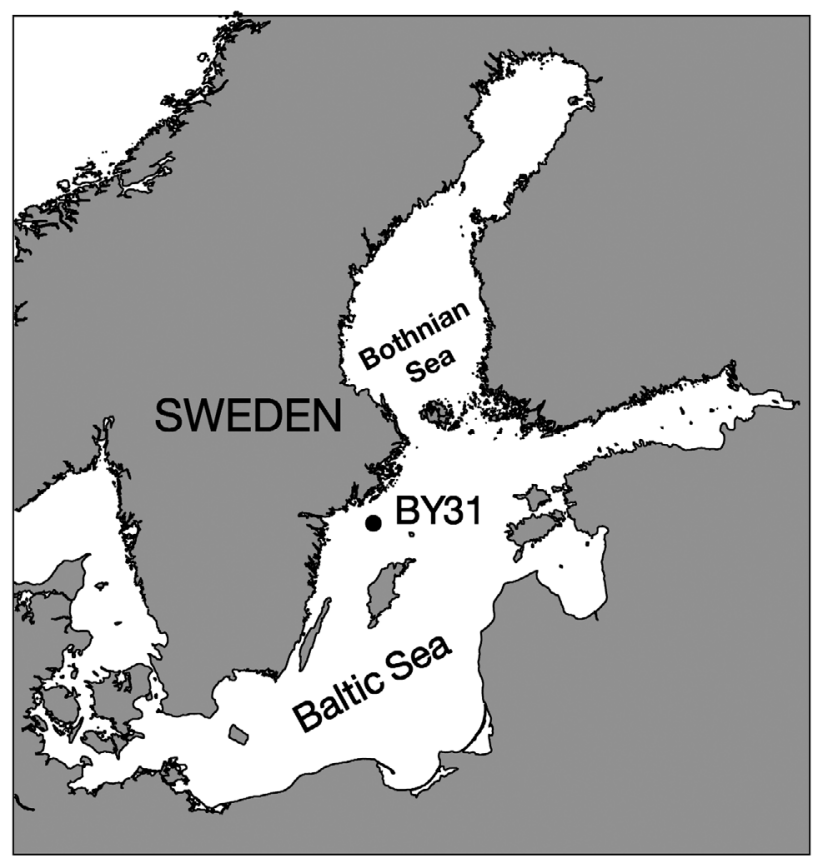

Fig. 1. Location of the sampling station BY31 (Landsort Deep), NW Baltic Sea proper bon fluxes are severely biased by migrating species entering the traps (Heiskanen 1995, 1998).

This study of the spring phytoplankton bloom in the offshore Baltic Sea proper aimed to quantify the settling flux of carbon and how it was influenced by the species composition of the bloom. The study site, the Landsort Deep, is the deepest in the Baltic Sea (459 m) and has a well-studied phytoplankton species composition (Larsson \& Hajdu 1997, Hajdu 2002). We quantified the contribution of different species to the spring vertical carbon flux using microscopical analysis of phytoplankton in the water column and in settled material as well as carbon analysis of settled particulate organic carbon (POC). We focused on the diatoms and dinoflagellates, which dominate the spring phytoplankton biomass and are easily recognisable in microscopic analysis.

\section{MATERIALS AND METHODS}

Phytoplankton and sedimentation. We sampled the Landsort Deep station (BY31, 58 $35^{\circ} \mathrm{N}, 18^{\circ} 14^{\prime} \mathrm{E}$, depth $459 \mathrm{~m}$, Fig. 1) weekly during the 1996 spring bloom (March 26 to May 7). Phytoplankton samples were taken at $0,2.5,5,10,20,30,40,50,60$ and $80 \mathrm{~m}$ with serial 51 water samplers (Hydrobios). Subsamples of $200 \mathrm{ml}$ were immediately preserved with acetic Lugol's solution $\left(0.75 \mathrm{ml}\right.$ Lugol $200 \mathrm{ml}^{-1}$ seawater). Settling material was collected in gimbal suspended cylindrical sediment traps (dual cylinders with inner diameter of $10.5 \mathrm{~cm}$, height $50 \mathrm{~cm}$, Larsson et al. 1986a) from March 26 to May 21. Before deployment, $2 \mathrm{ml}$ of chloroform was added as preservative. The traps were moored at 25,50 and $100 \mathrm{~m}$ depth, $5 \mathrm{n}$ miles east of BY31 $\left(58^{\circ} 36^{\prime} \mathrm{N}, 18^{\circ} 23^{\prime} \mathrm{E}\right.$, depth $\left.180 \mathrm{~m}\right)$ to reduce the impact of long anchor lines on the vertical position of traps exposed to currents. We have no indication of systematic differences between the 2 locations that would jeopardize comparison of water column and sediment trap data.

One set of traps was emptied weekly from March 26 to May 7, and finally on May 21 for counts and identification of settling cells. The April 23 to 30 sample from $25 \mathrm{~m}$ depth was lost. Upon retrieval, water was siphoned from the trap cylinders and the remaining sediment with some water was allowed to settle overnight in Imhoff funnels in darkness at $5^{\circ} \mathrm{C}$. The clear supernatant was siphoned off and the remaining aliquot diluted to $199 \mathrm{ml}$ with (filtered) seawater and $1 \mathrm{ml}$ acetic Lugol's solution. Two more sets of traps were used to collect material for carbon analysis and were emptied every second week (March 26 to May 21). Settling material from the 2 trap cylinders per set was pooled to obtain enough material for analysis. 
Zooplankters were removed with a $250 \mu \mathrm{m}$ net and the remaining sample treated as described in Blomqvist \& Larsson (1994). Carbon content was determined with a LECO CHN-analyser (CHN-900, 600-800-300, EDTA as standard).

Dominating phytoplankton species (diatoms and dinoflagellates) in the water column and sediment trap samples were counted after sedimentation in settlingchambers (10 to $50 \mathrm{ml}$ ), using an inverted microscope (Leica DM IRB and Wild M-40). Before enumeration, sediment trap samples were diluted with 7 ppt $\mathrm{NaCl}$ solution to obtain a suitable cell density. A magnification of 100 to $300 \times$ was used for cell counts and 200 to $600 \times$ for size measurements. A minimum of 50 units (cells or colonies) of the dominating species were counted and measured per sample, giving a maximum counting error of $\pm 28 \%$ (corresponding to a $95 \%$ confidence limit for the counts) (Lund et al. 1958, HELCOM 1988). We used linear interpolation to calculate cell densities in the depth intervals $0-25,25-50$ and 50-100 m (as cells $\mathrm{m}^{-2}$ ). Cell densities at $25 \mathrm{~m}$ depth were calculated as the mean of densities at 20 and $30 \mathrm{~m}$, and cell densities at $100 \mathrm{~m}$ were assumed to be the same as at $80 \mathrm{~m}$ depth. Phytoplankton cell volumes were calculated from size measurements according to Edler (1979), with modifications given in HELCOM (1988). Mean cell volumes were calculated for every species for each sampling date, depth and depth-interval based on cell size measurements. Cell volumes were converted to carbon according to Menden-Deuer \& Lessard (2000). Compared to carbon calculations according to Edler (1979), commonly used in publications from the Baltic Sea region, Menden-Deuer \& Lessard (2000) gives 15 to $30 \%$ higher carbon content for diatoms encountered in this study, while the carbon content of dinoflagellates are about the same $( \pm 4 \%$ compared to Edler 1979).

Daily sedimentation loss rates for the phytoplankton species were calculated as the proportion (\%) of the average cell concentration (cells $\mathrm{m}^{-2}$ ) in the $0-25 \mathrm{~m}$ water column (standing stock) that was recovered per day in the $25 \mathrm{~m}$ sediment trap.

Hydrography. Salinity (PSU) and water temperature were measured with a CTD-probe (Meerestechnik Elektronik) and water density calculated as sigma-t $\left(\sigma_{t}\right)$. We assumed that the mixed layer extended down to the top of the seasonal pycnocline (the depth where $\sigma_{\mathrm{t}}$ changed more than $\left.\sim 0.03 \mathrm{~m}^{-1}\right)$. Water for inorganic nutrient analysis was taken from $0,5,10,15,20,25,30$, $40,50,60,70,80$ and $100 \mathrm{~m}$ depth with serial $5 \mathrm{l}$ water samplers (Hydrobios). Standard flow injection analysis (QuikChem ${ }^{\circledR} 8000$ Method 31-115-01-3-A, 31-107-041-A, 31-107-06-1-A and 31-115-01-3-B Lachat Instruments) was used to measure dissolved inorganic phosphorus (DIP), nitrogen (DIN) $\left(\mathrm{NO}_{2}{ }^{-}+\mathrm{NO}_{3}{ }^{-}+\mathrm{NH}_{4}{ }^{+}\right)$and silica (DSi). A nutrient was considered depleted when its concentration was close to the detection-limit (DIP; $0.015 \mu \mathrm{M}$, DIN; $0.05 \mu \mathrm{M}$, DSi $0.1 \mu \mathrm{M}$ ).

Phytoplankton primary production. Rates of ${ }^{14} \mathrm{C}$-uptake were determined in $80 \mathrm{ml}$ polycarbonate bottles at $0,1,2,4,6,8,10,12.5,15,20,25$ and $30 \mathrm{~m}$ depth (production below $20 \mathrm{~m}$ low, $<0.6 \mu \mathrm{g} \mathrm{Cl}^{-1}$ ), with dark bottles at 0,4 and $25 \mathrm{~m}$. Each bottle received $4 \mu \mathrm{Ci}$ of carrier-free $\mathrm{NaH}^{14} \mathrm{CO}_{3}$. After in situ incubation for ca. $4 \mathrm{~h}$ around noon, $10 \mathrm{ml}$ sub-samples of unfiltered seawater were transferred to glass scintillation vials, 2 drops of $1 \mathrm{M} \mathrm{HCl}$ added and bubbled with air for at least $30 \mathrm{~min}$ before adding $10 \mathrm{ml}$ of Lumagel Safe (Lumac LSC B.V.) and counting in a Tri-Carb 1600 TR (Packard).

Total carbon dioxide concentration and carbon uptake was calculated according to Öström (1974). Dark uptake was calculated by linear interpolation between the incubation depths and subtracted from the light uptake. Daily primary production was calculated by multiplying by total daily insolation and dividing by insolation during the incubation period. Integrated ${ }^{14} \mathrm{C}$ uptake rates were linearly interpolated over depth.

Chlorophyll a. Chlorophyll a samples (2 1) from 0, 5, $10,15,20,30,40,50,60$ and $80 \mathrm{~m},(3 \mathrm{ml}$ magnesium hydroxide carbonate, $10 \mathrm{~g} \mathrm{l}^{-1}$ added per sample) were collected on Whatman GF/F filters (47 mm Ø), which were wrapped in aluminium foil and stored frozen $\left(-20^{\circ} \mathrm{C}\right)$. Filters were homogenised in $90 \%$ acetone with a piston grinder, centrifuged and the clear supernatant analysed in a Hitachi U2000 spectrophotometer. Calculations followed Jeffrey \& Humphrey (1975).

Contour plots. Contour plots of the vertical distribution patterns of environmental variables and phytoplankton species were generated in Surfer ${ }^{\circledR} 8.0$ using triangulation with linear interpolation.

Statistics. Approximation of coefficient of variation for the phytoplankton biomass: Biomass of individual phytoplankton species was calculated as the product of cell abundance and the estimated mean cell volume for each sample depth. Since time restrictions prevented replication and it was assumed that the 2 measurements were independent, we used the propagation of error formula (Rice 1993) to estimate variation of the biomass estimates:

$$
C_{\mathrm{b}} \approx \sqrt{C_{\mathrm{a}}^{2}+C_{\mathrm{v}}^{2} / n}
$$

where $C_{\mathrm{b}}, C_{\mathrm{a}}$ and $C_{\mathrm{v}}$ are the coefficients of variation for biomass, cell abundance and cell volume, respectively and $n$ is the number of counted cells.

If we assume that the cell abundance is Poissondistributed, then $C_{a}=\sqrt{1 / n}$ (Lund et al. 1958, Venrick 1978). For each sample, a minimum of 50 units were counted and measured, resulting in a $C_{\mathrm{a}}$ of maximum $14 \%$. 
The coefficient of variation for the cell volume $\left(C_{\mathrm{v}}\right)$ was estimated from cell volume measurements for all species and equalled $45 \%$. Insertion in Eq. (1) gives a maximum coefficient of variation for the biomass $\left(C_{\mathrm{b}}\right)$ of $15.5 \%$. The addition of the volume measurement error only increased the biomass coefficient of variation from 14 to $15.5 \%$, i.e. the main contribution to the biomass error is from the number of counted cells per sample.

Comparisons of phytoplankton carbon (PC) and total particulate organic carbon (POC) in sediment traps: Estimates of phytoplankton carbon were assumed to have the same maximum coefficient of variation $\left(C_{\mathrm{PC}}\right)$ as biomass $\left(C_{\mathrm{b}} 15.5 \%\right)$ since it was calculated by multiplying biomass with a fixed factor.

The total particulate organic carbon was estimated from duplicate samples and we used all samples to estimate the coefficient of variation to $C_{\mathrm{POC}}=9.1 \%$.

Approximate $95 \%$ confidence intervals for PC and POC were calculated using the estimated coefficients of variation and assuming normally distributed data.

For each depth, the ratio PC/POC was calculated and a test was made of the hypothesis that all particulate organic carbon found in a sediment trap is phyto- plankton carbon, i.e. $H_{0}: \mathrm{PC} / \mathrm{POC}=1$. The coefficient of variation for this ratio $\left(C_{\mathrm{PC} / \mathrm{POC}}\right)$ was calculated according to Eq. (1) and gave:

$$
C_{\mathrm{PC} / \mathrm{POC}} \approx \sqrt{C_{\mathrm{PC}}^{2}+C_{\mathrm{POC}}^{2}}=\sqrt{0.155^{2}+0.091^{2}} \approx 0.18
$$

The test was done assuming normally distributed data and the test score used was:

$$
\mathrm{z}=[(\mathrm{PC} / \mathrm{POC})-1] /\left(\mathrm{C}_{\mathrm{PC} / \mathrm{POC}} \cdot \mathrm{PC} / \mathrm{POC}\right)
$$

p-values $<0.05$ were regarded as significant.

\section{RESULTS}

\section{Hydrography and nutrients}

The water temperature in the top $30 \mathrm{~m}$ of the water column was near $0^{\circ} \mathrm{C}$ in March (Fig. 2a), gradually increasing to about $3.5^{\circ} \mathrm{C}$ in mid-May. A seasonal pycnocline gradually formed due to salinity stratification of the surface water, with mixed layer depth decreasing from 30 to about $15 \mathrm{~m}$ by mid to late March, and then varying between 5 and $20 \mathrm{~m}$ (Fig. 2b, c). Mixed layer salinity varied from 6.2 to 6.8 (Fig. 2 b) with occa-
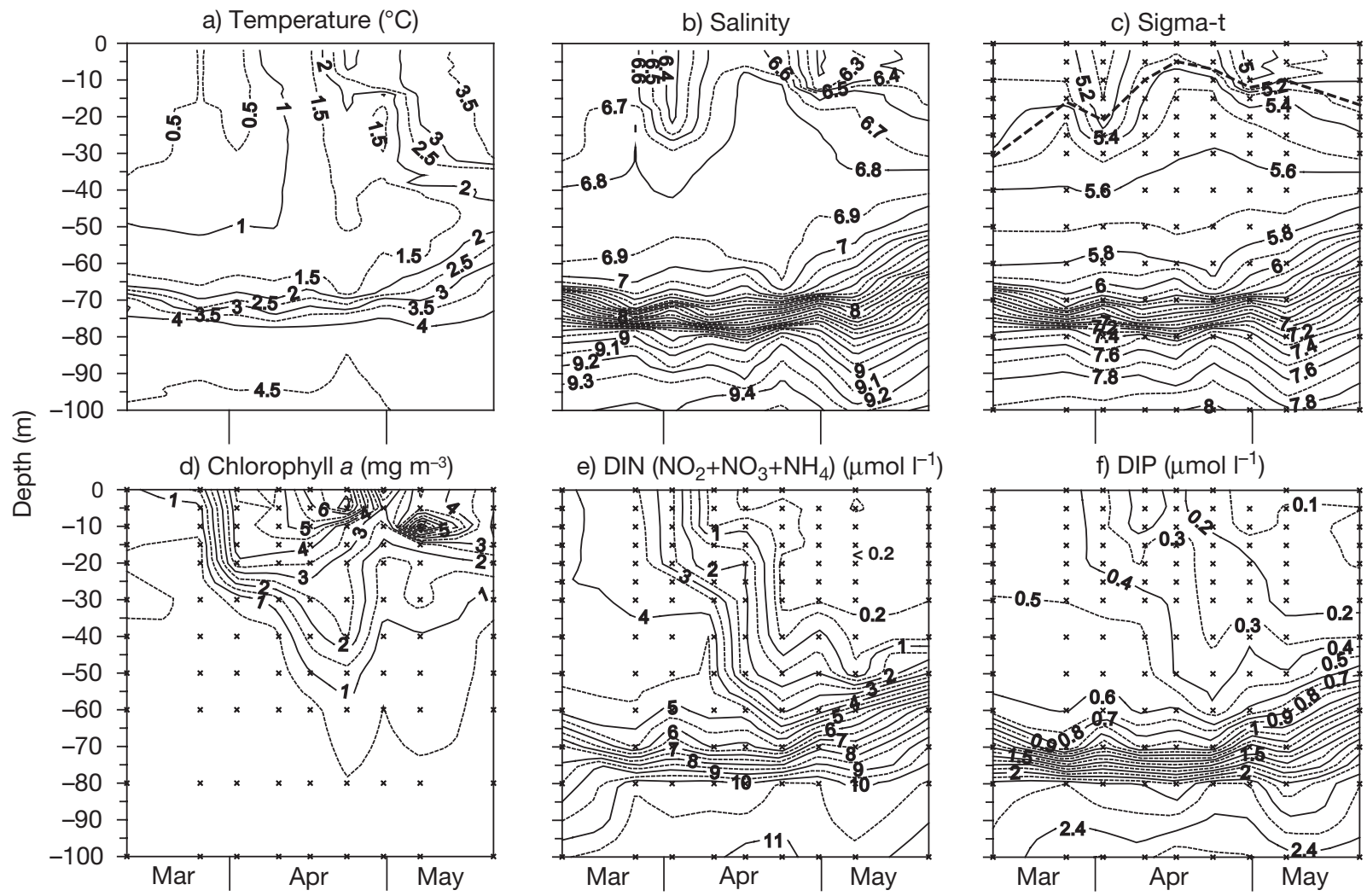

e) DIN $\left(\mathrm{NO}_{2}+\mathrm{NO}_{3}+\mathrm{NH}_{4}\right)\left(\mu \mathrm{mol} \mathrm{I}{ }^{-1}\right)$ f) DIP $\left(\mu \mathrm{mol} \mathrm{I}{ }^{-1}\right)$
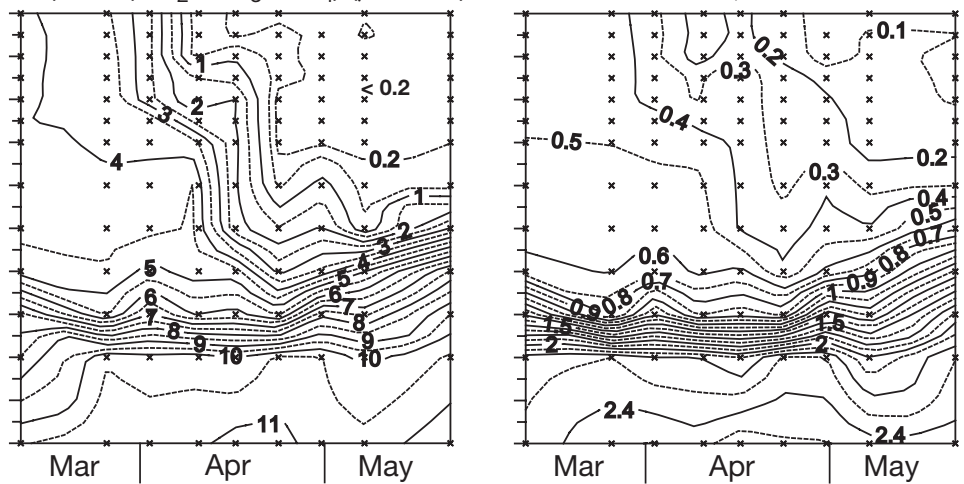

Fig. 2. Hydrography and dissolved inorganic nutrients at the sampling station March to May 1996. (a) Temperature ( $\left.{ }^{\circ} \mathrm{C}\right),(b)$ salinity, (c) sigma-t with mixed layer depth indicated by a broken bold line, (d) chlorophyll a $\left(\mathrm{mg} \mathrm{m}^{-3}\right)$, (e) nitrogen $\left(\mathrm{DIN}=\mathrm{NO}_{2}+\right.$ $\left.\mathrm{NO}_{3}+\mathrm{NH}_{4}\right)\left(\mu \mathrm{mol} \mathrm{l}^{-1}\right)$ and (f) phosphate $\left(\mathrm{DIP}=\mathrm{PO}_{4}\right)\left(\mu \mathrm{mol} \mathrm{l}^{-1}\right)$. Sampling depths indicated by $\times$ in $\mathrm{C}-\mathrm{f}$ 
sional drops indicating spring flood influence from coastal sources or low salinity water from the Bothnian Sea to the north. Water temperature and salinity remained relatively stable below the mixed layer, and down to the permanent halocline at 60 to $80 \mathrm{~m}$ depth (Fig. 2a, b).

The spring phytoplankton bloom commenced in early April, when chl a increased 4-fold from 1 to $4 \mathrm{mg} \mathrm{m}^{-3}$ (Fig. 2d). By mid April, the dissolved inorganic nitrogen (DIN) was depleted in the mixed layer and $2 \mathrm{wk}$ later to $30 \mathrm{~m}$ depth (Fig. 2e). Nitrogen controlled the spring bloom since neither DIP (Fig. 2f) nor silica were depleted (silica decreased from 14 to $9 \mu \mathrm{M}$, data not shown).

\section{Vertical distribution of common diatoms and dinoflagellates}

Initially, the diatoms Chaetoceros spp. (mainly $C$. wighamii Brightwell, some C. holsaticus Schütt) and Achnanthes taeniata Grunow (syn. with Pauliella taeniata [Grunow] Round \& Basson) dominated in the surface layer (0 to $20 \mathrm{~m}$ ), while Thalassiosira levanderi van Goor, Thalassiosira baltica (Grunow) Ostenfeld and Skeletonema costatum (Greville) Cleve were sparse (Table 1). Early in the bloom, A. taeniata was restricted to the top $30 \mathrm{~m}$, but $3 \mathrm{wk}$ later, a considerable biomass was found below the seasonal pycnocline, down to $50 \mathrm{~m}$ depth (Fig. 3a). Chaetoceros spp. settled from the mixed surface layer within a week of its peak biomass, with a tendency to biomass accumulation at the top of the permanent halocline and very few cells below (Fig. 3b). Virtually no $S$. costatum (Fig. 3c) or T. levanderi (Fig. 3d) were found below $30 \mathrm{~m}$ depth, in contrast to $T$. baltica, which was found down to $80 \mathrm{~m}$ depth especially at the end of the period (Fig. 3e).

Around April 10, the spring bloom dinoflagellate cf. Scrippsiella hangoei (Schiller) Larsen increased in biomass (Fig. 3f). Two weeks later, diatoms were virtually absent while another dinoflagellate, Peridiniella catenata (Levander) Balech (Fig. 3g), was co-dominant with $S$. hangoei and later, totally dominated the final bloom phase (Fig. 4a). Neither dinoflagellate species was found below $50 \mathrm{~m}$ depth, except for a low biomass (3 to $10 \mathrm{mg} \mathrm{C} \mathrm{m}^{-3}$ ) of $S$. hangoei at 60 and $80 \mathrm{~m}$ depth in early May (Fig. 4a), but both species had considerable biomass below the upper mixed layer late in the bloom (Fig. 3f, g).

According to data from the regular phytoplankton monitoring at this station, the aforementioned diatom and dinoflagellate species made up 80 to $90 \%$ of the total phytoplankton biomass $>2 \mu \mathrm{m}$ during the 1996 spring bloom (Larsson \& Hajdu 1997).

\section{Species-specific settling}

Sedimentation patterns were species-specific and the proportion of each species in the sediment traps differed from those in the water column (Table $1 \&$ Fig. 4b). Thalassiosira levanderi and T. baltica were proportionally more, and Scrippsiella hangoei and Chaetoceros spp. less common in the sediment trap material, than in the water column samples (Table 1 \& Fig. 4). Consequently, the first 2 species had comparatively higher sedimentation loss rates than the latter 2 species (Table 2 \& Fig. 4b). Of the dinoflagellates, $S$. hangoei was particularly scarce in the sediment trap material (Table 1 \& Fig. 4b), while Peridiniella catenata dominated in the 0 to $50 \mathrm{~m}$ water column late in the bloom as well as in the 25 and $50 \mathrm{~m}$ sediment traps, but was virtually absent below $50 \mathrm{~m}$ and in the $100 \mathrm{~m}$ trap (Fig. 4b).

Early in the bloom, settling was low and the few cells found in the traps were mostly Achnanthes taeniata and T. levanderi (Fig. 4b). A. taeniata biomass peaked in the water column already $1 \mathrm{wk}$ after the bloom start, but occurred in low biomass throughout the bloom (Fig. 4a) and was a substantial part of cells found in traps at all depths (Fig. 4b \& Table 1). T. levanderi dominated the shallow trap already in the second week and with time, made up a considerable part of the cells in the intermediate and deep traps. T. baltica showed a similar settling pattern (Fig. 4b).

\section{Settled phytoplankton carbon and total particulate organic carbon}

Sedimentation of phytoplankton carbon as intact cells (PC) and total particulate organic carbon (POC) was low early in the bloom (March 26 to April 10) (Table 3). While POC and PC was similar at $25 \mathrm{~m}$ (19 to $24 \mathrm{mg} \mathrm{C}$ $\mathrm{m}^{-2} \mathrm{~d}^{-1}$ ), the amount of PC decreased with depth and was significantly lower $(\mathrm{p}<0.001)$ than POC at 50 and $100 \mathrm{~m}$ (Table 3). Following the decline of the diatom bloom in mid-April, sedimentation of both POC and PC increased at all depths. From April 10 to May 7, all the settled POC was equal to PC at 25 and $50 \mathrm{~m}$ (Table 3), while less than $25 \%$ of the POC could be identified as phytoplankton carbon at $100 \mathrm{~m}$. In May (May 7 to 21), when the diatoms were gone from the water column (Figs. 3 \& 4a), POC remained high (>100 $\mathrm{mg} \mathrm{C} \mathrm{m}^{-2} \mathrm{~d}^{-1}$ ), but only $24 \%$ of it could be identified as PC at 25 and $50 \mathrm{~m}$, and even less, $10 \%$, at $100 \mathrm{~m}$ (Table 3).

\section{Primary production versus phytoplankton sedimentation}

During the initial phase of the bloom (March 26 to April 16), little (2 to $7 \%$ ) of the daily primary produc- 
Table 1. Average phytoplankton carbon biomass $\left(\mathrm{mg} \mathrm{C} \mathrm{m}^{-2}\right)$ in different depth intervals during the deployment of the sediment traps and phytoplankton biomass in sediment traps (mg C m ${ }^{-2} \mathrm{~d}^{-1}$ ) (March 26-May 21). Percent (\%) of total phytoplankton biomass per depth interval or depth in brackets. nd = no data

\begin{tabular}{|c|c|c|c|c|c|c|c|}
\hline \multirow[t]{2}{*}{ Species } & \multirow{2}{*}{$\begin{array}{c}\text { Date } \\
\mathrm{dd} / \mathrm{mm}\end{array}$} & \multicolumn{3}{|c|}{ Water column $\left(\mathrm{mg} \mathrm{C} \mathrm{m}{ }^{-2}\right)$} & \multicolumn{3}{|c|}{ - Sediment trap $\left(\mathrm{mg} \mathrm{C} \mathrm{m}^{-2} \mathrm{~d}^{-1}\right)$} \\
\hline & & $0-25 \mathrm{~m}$ & $25-50 \mathrm{~m}$ & $50-100 \mathrm{~m}$ & $25 \mathrm{~m}$ & $50 \mathrm{~m}$ & $100 \mathrm{~m}$ \\
\hline \multirow{7}{*}{$\begin{array}{l}\text { Achnanthes } \\
\text { taeniata }\end{array}$} & $26 / 03-02 / 04$ & $573(53)$ & $25(34)$ & $0(-)$ & $5(54)$ & $1(58)$ & $0.7(78)$ \\
\hline & $02 / 04-10 / 04$ & $683(18)$ & $30(12)$ & $0(-)$ & $2(8)$ & $0.4(11)$ & $0.6(31)$ \\
\hline & $10 / 04-16 / 04$ & $190(5)$ & $53(8)$ & $13(10)$ & $20(35)$ & $33(52)$ & $0.5(21)$ \\
\hline & $16 / 04-23 / 04$ & $155(4)$ & $268(13)$ & $102(22)$ & $24(15)$ & $19(20)$ & $3(24)$ \\
\hline & $23 / 04-30 / 04$ & $131(5)$ & $349(17)$ & $157(29)$ & nd & $20(16)$ & $9(26)$ \\
\hline & $30 / 04-07 / 05$ & $63(3)$ & 137 (13) & $97(20)$ & $4(2)$ & $13(9)$ & $9(40)$ \\
\hline & $07 / 05-21 / 05$ & $21(<1)$ & $17(2)$ & $56(11)$ & $0.6(2)$ & $2(4)$ & $2(11)$ \\
\hline \multirow{7}{*}{$\begin{array}{l}\text { Chaetoceros } \\
\text { spp. }\end{array}$} & $26 / 03-02 / 04$ & $274(25)$ & $34(46)$ & $0.2(81)$ & $0.7(8)$ & $0.2(7)$ & $0(-)$ \\
\hline & $02 / 04-10 / 04$ & $1389(37)$ & $71(29)$ & $2(81)$ & $2(7)$ & $1(24)$ & $0.5(28)$ \\
\hline & $10 / 04-16 / 04$ & $1717(42)$ & 398 (59) & $97(71)$ & $10(18)$ & $5(8)$ & $0.3(14)$ \\
\hline & $16 / 04-23 / 04$ & 615 (17) & 399 (19) & $266(58)$ & $4(3)$ & $12(13)$ & 3 (23) \\
\hline & $23 / 04-30 / 04$ & 87 (3) & $75(4)$ & $231(42)$ & nd & $3(2)$ & $15(43)$ \\
\hline & $30 / 04-07 / 05$ & $52(2)$ & $34(3)$ & $65(13)$ & $0.2(<1)$ & $2(2)$ & $4(17)$ \\
\hline & $07 / 05-21 / 05$ & $7(<1)$ & $2(<1)$ & $8(2)$ & $0.2(1)$ & $0.3(<1)$ & $1(6)$ \\
\hline \multirow{7}{*}{$\begin{array}{l}\text { Skeletonema } \\
\text { costatum }\end{array}$} & $26 / 03-02 / 04$ & $10(1)$ & $1(2)$ & $<0.1$ (19) & $<0.1(<1)$ & $<0.1(<1)$ & $0(-)$ \\
\hline & $02 / 04-10 / 04$ & $23(1)$ & $2(1)$ & $0(-)$ & $0.1(<1)$ & $<0.1(<1)$ & $<0.1(<1)$ \\
\hline & $10 / 04-16 / 04$ & $17(<1)$ & $1(<1)$ & $0.1(<1)$ & $0.3(<1)$ & $0.2(<1)$ & $<0.1(<1)$ \\
\hline & $16 / 04-23 / 04$ & $4(<1)$ & $0.6(<1)$ & $0.4(<1)$ & $0.3(<1)$ & $0.6(<1)$ & $0.2(2)$ \\
\hline & $23 / 04-30 / 04$ & $1(<1)$ & $1(<1)$ & $1(<1)$ & nd & $0.1(<1)$ & $0.6(2)$ \\
\hline & $30 / 04-07 / 05$ & $1(<1)$ & $0.8(<1)$ & $1(<1)$ & $<0.1(<1)$ & $0.1(<1)$ & $0.3(1)$ \\
\hline & $07 / 05-21 / 05$ & $0(-)$ & $0(-)$ & $0(<1)$ & $<0.1(<1)$ & $<0.1(<1)$ & $<0.1(<1)$ \\
\hline \multirow{7}{*}{$\begin{array}{l}\text { Thalassiosira } \\
\text { baltica }\end{array}$} & $26 / 03-02 / 04$ & $62(6)$ & $4(5)$ & $0(-)$ & $1(12)$ & $0.4(16)$ & $0.2(22)$ \\
\hline & $02 / 04-10 / 04$ & $95(3)$ & $13(5)$ & $0(-)$ & $3(10)$ & $0.2(6)$ & $0.2(9)$ \\
\hline & $10 / 04-16 / 04$ & $83(2)$ & $44(7)$ & $8(6)$ & $10(17)$ & $6(10)$ & $0.3(11)$ \\
\hline & $16 / 04-23 / 04$ & $86(2)$ & $88(4)$ & $50(11)$ & $16(10)$ & $7(7)$ & $0.7(5)$ \\
\hline & $23 / 04-30 / 04$ & $96(3)$ & $98(5)$ & 98 (18) & nd & $21(17)$ & $3(7)$ \\
\hline & $30 / 04-07 / 05$ & $62(3)$ & $81(8)$ & $108(22)$ & $3(2)$ & $16(10)$ & $3(12)$ \\
\hline & $07 / 05-21 / 05$ & $5(<1)$ & $69(6)$ & $106(20)$ & $3(11)$ & $4(9)$ & $3(18)$ \\
\hline Thalassiosira & $26 / 03-02 / 04$ & $51(5)$ & 7 (9) & $0(-)$ & $2(24)$ & $0.4(16)$ & $0(-)$ \\
\hline \multirow[t]{6}{*}{ levanderi } & $02 / 04-10 / 04$ & $98(3)$ & $27(11)$ & 0.4 (19) & $20(74)$ & $2(58)$ & $0.2(12)$ \\
\hline & $10 / 04-16 / 04$ & $63(2)$ & $29(4)$ & $5(4)$ & $9(16)$ & $16(26)$ & $1(43)$ \\
\hline & $16 / 04-23 / 04$ & $15(<1)$ & $10(<1)$ & $9(2)$ & $8(5)$ & $26(28)$ & $5(37)$ \\
\hline & $23 / 04-30 / 04$ & $0.6(<1)$ & $2(<1)$ & $4(1)$ & nd & $2(2)$ & $6(17)$ \\
\hline & $30 / 04-07 / 05$ & $0.2(<1)$ & $0(-)$ & $0(-)$ & $0(-)$ & $0(-)$ & $0.5(2)$ \\
\hline & $07 / 05-21 / 05$ & $0(-)$ & $0(-)$ & $0(-)$ & $0(-)$ & $0(-)$ & $0.1(1)$ \\
\hline \multirow{7}{*}{$\begin{array}{l}\text { Peridiniella } \\
\text { catenata }\end{array}$} & $26 / 03-02 / 04$ & $66(6)$ & $2(3)$ & $0(-)$ & $<0.1(<1)$ & $0.1(4)$ & $0(-)$ \\
\hline & $02 / 04-10 / 04$ & $195(5)$ & 7 (3) & $0(-)$ & $0(-)$ & $<0.1(<1)$ & $0.4(20)$ \\
\hline & $10 / 04-16 / 04$ & $272(7)$ & $17(3)$ & $0(-)$ & $8(13)$ & $3(5)$ & $0.3(11)$ \\
\hline & $16 / 04-23 / 04$ & $704(20)$ & $487(24)$ & $18(4)$ & $110(67)$ & $29(31)$ & $1(9)$ \\
\hline & $23 / 04-30 / 04$ & $1041(36)$ & $624(31)$ & $18(3)$ & nd & 75 (59) & $0.6(2)$ \\
\hline & $30 / 04-07 / 05$ & $1759(84)$ & 594 (57) & $41(8)$ & 144 (93) & 105 (68) & $0.2(<1)$ \\
\hline & $07 / 05-21 / 05$ & $2560(94)$ & $887(76)$ & $81(15)$ & $19(71)$ & $33(73)$ & $0.2(1)$ \\
\hline Scrippsiella & $26 / 03-02 / 04$ & $45(4)$ & $1(1)$ & $0(-)$ & 0.1 (1) & $<0.1(<1)$ & $0(-)$ \\
\hline \multirow{6}{*}{ hangoei } & $02 / 04-10 / 04$ & $1277(34)$ & 98 (39) & $0(-)$ & $0.2(<1)$ & $<0.1(<1)$ & $0(-)$ \\
\hline & $10 / 04-16 / 04$ & $1774(43)$ & 128 (19) & $14(10)$ & $0.1(<1)$ & $0.1(<1)$ & $<0.1(<1)$ \\
\hline & $16 / 04-23 / 04$ & 1953 (55) & $818(40)$ & $18(4)$ & $0.5(<1)$ & $<0.1(<1)$ & $<0.1(<1)$ \\
\hline & $23 / 04-30 / 04$ & $1522(53)$ & $885(44)$ & $42(8)$ & nd & $5(4)$ & $1(3)$ \\
\hline & $30 / 04-07 / 05$ & $162(8)$ & 192 (19) & $178(36)$ & $3(2)$ & $17(11)$ & $6(27)$ \\
\hline & $07 / 05-21 / 05$ & $145(5)$ & 186 (16) & $280(53)$ & $4(14)$ & $6(14)$ & $10(63)$ \\
\hline
\end{tabular}

tion settled as intact identifiable cells (Table 4). After the diatom peak in mid April, this fraction increased to $40 \%$ (Table 4 ). The total amount of carbon, estimated from cell counts, that settled into the $25 \mathrm{~m}$ trap during the whole spring period (26 March to 7 May) was $4 \mathrm{~g} \mathrm{C}$ $\mathrm{m}^{-2}$ or $16 \%$ of the primary production $\left(24.9 \mathrm{~g} \mathrm{C} \mathrm{m}^{-2}\right.$,
Table 5). A similar amount, $3 \mathrm{~g} \mathrm{C} \mathrm{m}^{-2}$ or $12 \%$ of the primary production, was estimated for the sediment trap at $50 \mathrm{~m}$, while only $0.5 \mathrm{~g} \mathrm{C} \mathrm{m}^{-2}$ or $2 \%$ of the primary production reached the $100 \mathrm{~m}$ sediment trap below the halocline in the form of intact cells (Table 5). The settled total particulate organic carbon (POC) (Table 5) 
was 3.0 to $3.1 \mathrm{~g} \mathrm{C} \mathrm{m}^{-2}$ for the same period at all 3 depths, i.e. only $12 \%$ of the primary production settled as POC.

\section{DISCUSSION}

\section{Settling of spring bloom primary production}

Temperate spring phytoplankton blooms are considered to export a considerable fraction of the primary production (PP) to deeper waters, but reported variability is large. Wassmann (1991), when compiling data from the Baltic Sea, Norwegian fjords and the Atlantic Ocean, found that between 14 and $85 \%$ (average $46 \%$ ) of the spring bloom primary production settled out. Most of the data were of coastal origin and potentially biased by resuspension (Blomqvist \& Larsson 1994). Methodological differences (trap designs, preservatives, exposure time etc.) further complicate comparison of different studies (Hargrave \& Burns 1979, Bloesch \& Burns 1980, Gardner 1980, Blomqvist \& Håkansson 1981). Much variability may also stem from differences in foodweb structure affecting sedimentation loss (Peinert et al. 1989, Wassmann 1998). Our results indicate a mixed layer spring settling loss at the lower end (4 $\mathrm{g} \mathrm{C} \mathrm{m}^{-2}$ or $\sim 15 \%$ of PP) given by Wassmann (1991). Stigebrandt (1991) used 25 yr of oxygen measurements and calculated oxygen fluxes through the sea surface to estimate net production of organic matter in the top $15 \mathrm{~m}$ of 2 Baltic Sea proper sub-areas to 38 and $49 \mathrm{~g} \mathrm{C} \mathrm{m}^{-2} \mathrm{yr}^{-1}$. Earlier, Rahm (1987) arrived at a similar export production estimate of $50 \mathrm{~g} \mathrm{C} \mathrm{m}^{-2} \mathrm{yr}^{-1}$, from calculations of below halocline oxygen consumption. Our carbon settling of 3 to $4 \mathrm{~g} \mathrm{C} \mathrm{m}^{-2}$ in spring is less than $10 \%$ of the above yearly estimates and may seem low in comparison, and recent calibration of similar traps as used in this study against ${ }^{234} \mathrm{Th}$ flux suggested under trapping in spring by a factor of about 2 (Gustafsson et al. 2004). Struck et al. (2004) arrived at similar new production estimates (28 to $66 \mathrm{~g} \mathrm{C} \mathrm{m}^{-2} \mathrm{yr}^{-1}$, calculated assuming $\mathrm{C} / \mathrm{N}=8$ ) as above but measured a very low flux of $1 \mathrm{~g} \mathrm{C} \mathrm{m}^{-2}$ (March-May, average 1995-1998) in traps moored at $140 \mathrm{~m}$ in the Eastern Gotland Basin. They concluded water column remineralisation to be very effective, particularly below the halocline. In addition to under-trapping, several factors may have added to a low carbon settling in 1996. Available time series suggest a between year variability in primary production of a factor of 2 and PP in 1996 was in the lower end of that range (U. Larsson pers. comm.). This, combined with an early shift from diatoms to dinoflagellates, likely resulted in a low settling loss.
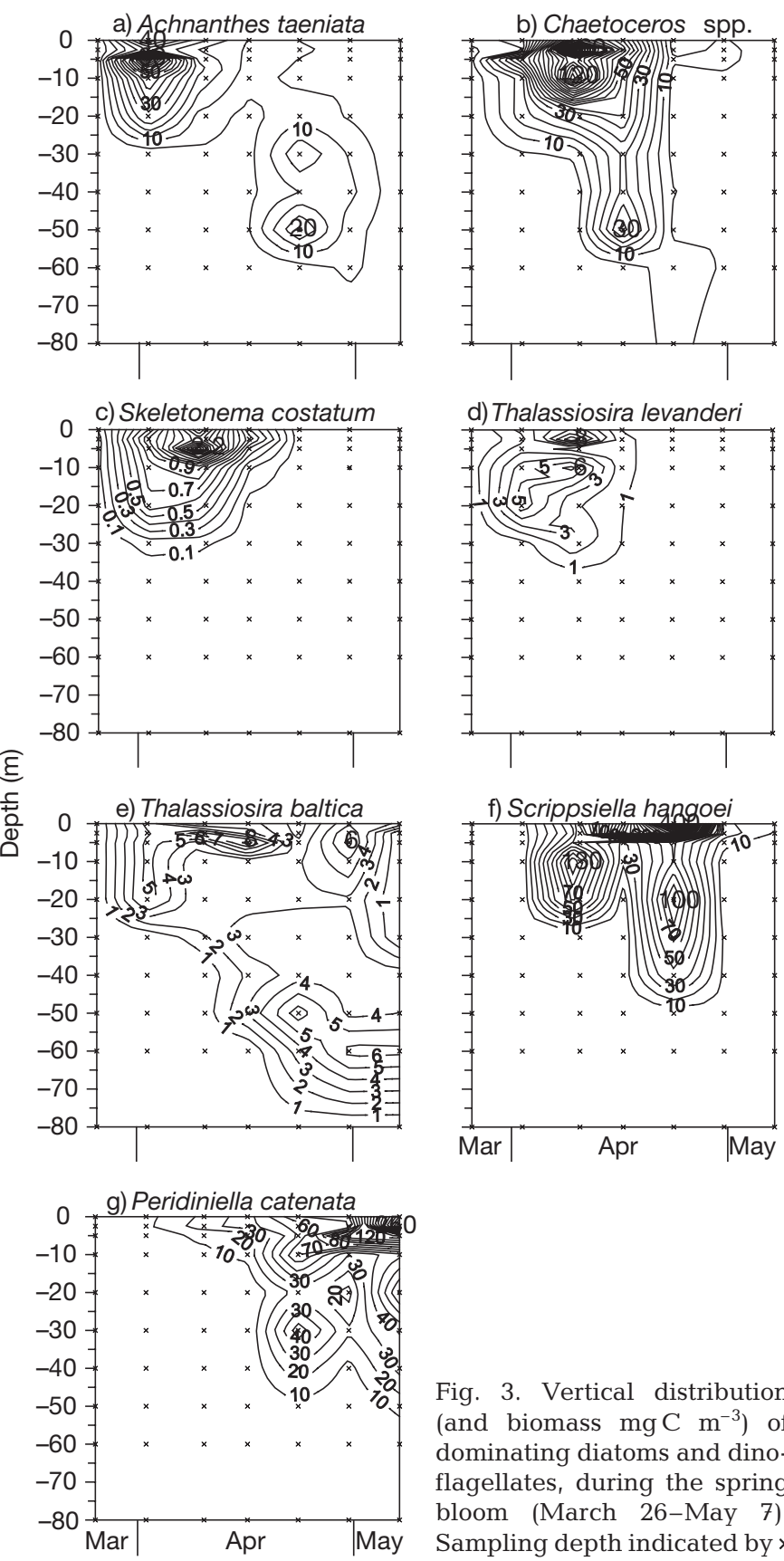

Fig. 3. Vertical distribution (and biomass $\mathrm{mgC}^{-3}$ ) of dominating diatoms and dinoflagellates, during the spring bloom (March 26-May 7). Sampling depth indicated by $x$

\section{Water column}

Kahru \& Nômmann (1990) concluded that the spring bloom in the Baltic Sea proper was initiated by salinity stratification and light since the bloom starts before the maximum density temperature (about $2.5^{\circ} \mathrm{C}$, Stigebrandt 2001) was reached in the surface water. They found spring blooms in the northern Baltic Sea proper to progress from the coast to the open sea and from north to south, with the central Baltic as the last area to bloom. The salinity stratification is provided by horizon- 

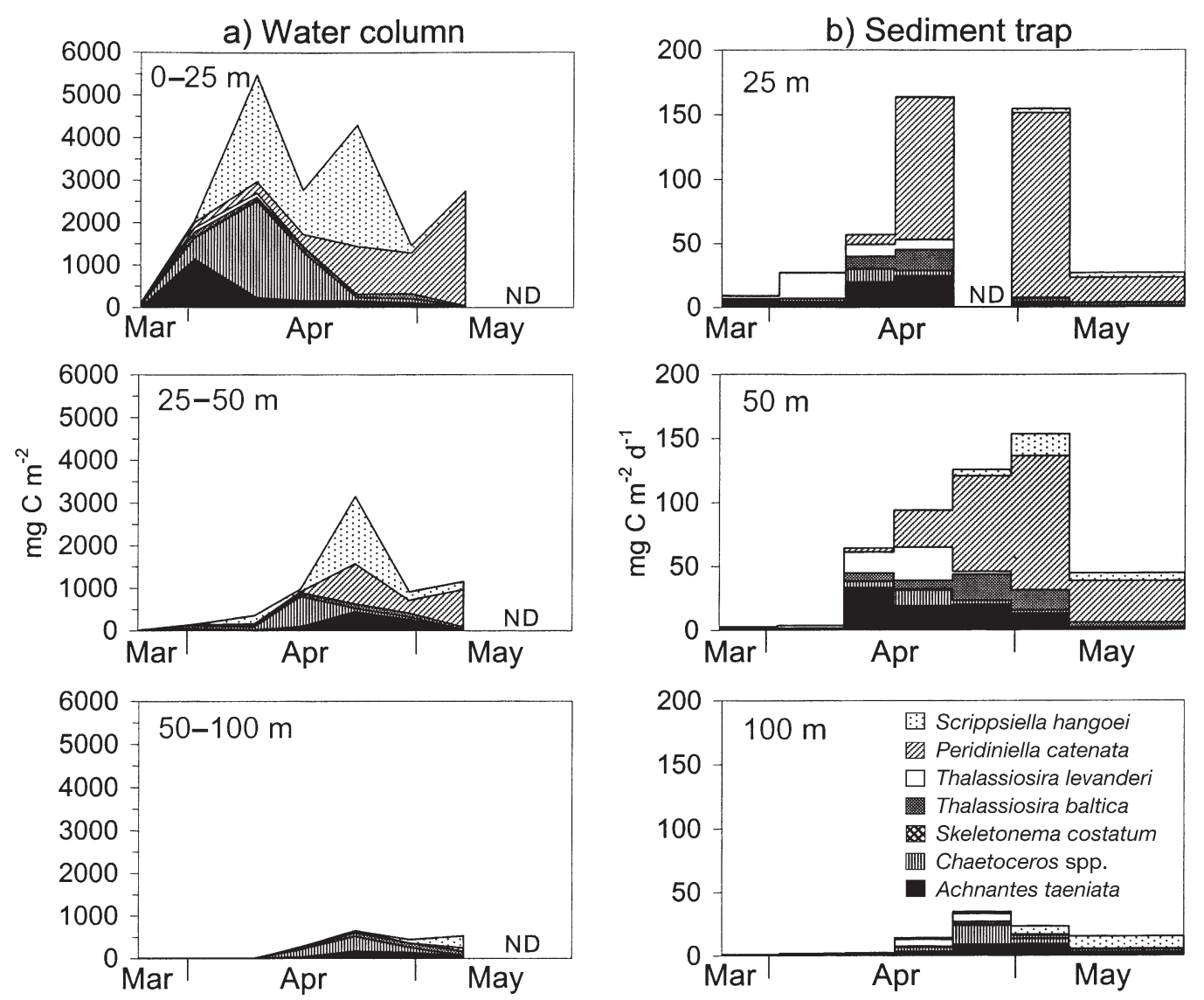

Fig. 4. Species composition in (a) integrated water column samples 0-25, 25-50 and 50-100 $\mathrm{m}$ (mg C m $\mathrm{m}^{-2}$ ), and (b) sediment trap samples from 25, 50 and $100 \mathrm{~m}$ depth $\left(\mathrm{mg} \mathrm{C} \mathrm{m}^{-2} \mathrm{~d}^{-1}\right)$ during the spring bloom in 1996 at the Landsort Deep station (BY31). (ND = no data)

Table 2. Settling ratio: Percentage (\%) of the average cell concentrations in the $0-25 \mathrm{~m}$ water column which settles daily at $25 \mathrm{~m}$ depth during the studied periods (March 26-May 7). nd = no data

\begin{tabular}{|c|c|c|c|c|c|c|c|}
\hline Date & $\begin{array}{c}\text { Achnanthes } \\
\text { taeniata }\end{array}$ & $\begin{array}{c}\text { Chaetoceros } \\
\text { spp. }\end{array}$ & $\begin{array}{c}\text { Skeletonema } \\
\text { costatum }\end{array}$ & $\begin{array}{c}\text { Thalassiosira } \\
\text { baltica }\end{array}$ & $\begin{array}{c}\text { Thalassiosira } \\
\text { levanderi }\end{array}$ & $\begin{array}{c}\text { Peridiniella } \\
\text { catenata }\end{array}$ & $\begin{array}{c}\text { Scrippsiella } \\
\text { hangoei }\end{array}$ \\
\hline $26 / 03-02 / 04$ & 1 & $<1$ & $<1$ & 2 & 5 & $<0.1$ & $<1$ \\
\hline $02 / 04-10 / 04$ & $<1$ & $<1$ & $<1$ & 3 & 16 & $\ll 0.1$ & $<0.1$ \\
\hline $10 / 04-16 / 04$ & 11 & $<1$ & 2 & 13 & 8 & 2 & $<0.1$ \\
\hline $16 / 04-23 / 04$ & 17 & 1 & 9 & 22 & 44 & 6 & $<0.1$ \\
\hline $23 / 04-30 / 04$ & nd & nd & nd & nd & nd & nd & nd \\
\hline $30 / 05-07 / 05$ & 6 & $<1$ & 1 & 5 & $\ll 0.1$ & 7 & 2 \\
\hline
\end{tabular}

tal advection of lower salinity water (Eilola 1997). This seems to be particularly important in the NW part of the Baltic Sea proper where juvenile freshwater from the Gulf of Bothnia spreads along the Swedish coast, probably in narrow coastal currents (Eilola \& Stigebrandt 1998). Such currents may well be responsible for the observed variability in surface salinity with time in the study area, if they change in direction and in salt content. They can also supply the surface water with the buoyancy needed to initiate the spring bloom (Kaiser \& Schulz 1978, Smetacek \& Passow 1990).
Less saline water originating from the Gulf of Bothnia is expected to carry other phytoplankton species, particularly after a winter with ice cover, as in 1996. The peak of the 'ice-alga' Achnanthes taeniata (Heacky et al. 1998) early in the bloom coincided with a marked drop in salinity. After salinity increased again, this species was only present in low abundance, indicating a replacement of the surface water. Although A. taeniata was also common in the ice-covered coastal area NW of station BY31 (H. Höglander unpubl. data), the comparatively low freshwater out- 
Table 3. Comparison of total settling particulate organic carbon (POC) and settling phytoplankton carbon (PC, estimated from cell counts) from March 26 to May 21. Biomass values in $\mathrm{mg} \mathrm{C} \mathrm{m}^{-2} \mathrm{~d}^{-1}$ with estimated $95 \%$ confidence limits (see 'Materials and methods'). Also given is phytoplankton carbon as \% of total settling particulate organic carbon, with estimated $95 \%$ confidence limits (see 'Materials and methods'). Hypothesis testing of $\mathrm{H}_{0}$ : $\mathrm{POC}=\mathrm{PC}$, i.e. $\mathrm{PC} / \mathrm{POC}$-ratio $=1$ with standardized normal distribution. ${ }^{*} \mathrm{p}<0.05,{ }^{* *} \mathrm{p}<0.01,{ }^{* * *} \mathrm{p}<0.001$, nd $=$ no data

\begin{tabular}{|c|c|c|c|c|}
\hline $\begin{array}{l}\text { Date } \\
\mathrm{dd} / \mathrm{mm}\end{array}$ & $\begin{array}{l}\text { Depth } \\
\text { (m) }\end{array}$ & $\begin{array}{l}\text { Total particulate organic } \\
\text { carbon (POC) } \\
\mathrm{mg} \mathrm{C} \mathrm{m}^{-2} \mathrm{~d}^{-1}\end{array}$ & $\begin{array}{c}\text { Phytoplankton carbon } \\
\qquad \begin{array}{c}\text { (PC) } \\
\text { mg C m } \mathrm{C}^{-2} \mathrm{~d}^{-1}\end{array}\end{array}$ & $\begin{array}{l}\text { Phytoplankton } \\
\text { carbon as \% of } \\
\text { POC }\end{array}$ \\
\hline $\begin{array}{l}26 / 03-10 / 04 \\
(15 \mathrm{~d})\end{array}$ & $\begin{array}{r}25 \\
50 \\
100\end{array}$ & $\begin{array}{l}24 \pm 4 \\
24 \pm 4 \\
39 \pm 7\end{array}$ & $\begin{aligned} 19 & \pm 6 \\
3 & \pm 1 \\
1 & \pm 0.4\end{aligned}$ & $\begin{aligned} 79 & \pm 29 \\
13 & \pm 5^{* * *} \\
4 & \pm 1^{* * *}\end{aligned}$ \\
\hline $\begin{array}{l}10 / 04-23 / 04 \\
(13 \mathrm{~d})\end{array}$ & $\begin{array}{r}25 \\
50 \\
100\end{array}$ & $\begin{array}{r}100 \pm 18 \\
101 \pm 18 \\
61 \pm 11\end{array}$ & $\begin{aligned} 114 & \pm 35 \\
80 & \pm 25 \\
9 & \pm 3\end{aligned}$ & $\begin{aligned} 114 & \pm 41 \\
80 & \pm 29 \\
14 & \pm 5^{* * *}\end{aligned}$ \\
\hline $\begin{array}{l}23 / 04-07 / 05 \\
(14 \mathrm{~d})\end{array}$ & $\begin{array}{r}25 \\
50 \\
100\end{array}$ & $\begin{array}{r}99 \pm 18 \\
95 \pm 17 \\
123 \pm 22\end{array}$ & $\begin{array}{c}\text { nd } \\
140 \pm 43 \\
29 \pm 9\end{array}$ & $\begin{array}{c}\text { nd } \\
147 \pm 53 \\
24 \pm 9^{* * *}\end{array}$ \\
\hline $\begin{array}{l}07 / 05-21 / 05 \\
(14 \mathrm{~d})\end{array}$ & $\begin{array}{r}25 \\
50 \\
100\end{array}$ & $\begin{array}{l}112 \pm 20 \\
198 \pm 36 \\
154 \pm 28\end{array}$ & $\begin{array}{l}27 \pm 8 \\
45 \pm 14 \\
15 \pm 5\end{array}$ & $\begin{array}{l}24 \pm 9^{* * *} \\
23 \pm 8^{* * *} \\
10 \pm 4^{* * *}\end{array}$ \\
\hline $\begin{array}{l}\text { Total } \\
26 / 03-21 / 05 \\
(56 \mathrm{~d})\end{array}$ & $\begin{array}{r}25 \\
50 \\
100\end{array}$ & $\begin{array}{r}82 \pm 15 \\
103 \pm 19 \\
92 \pm 17\end{array}$ & $\begin{array}{l}77 \pm 24^{\mathrm{a}} \\
66 \pm 20 \\
13 \pm 4\end{array}$ & $\begin{array}{l}94 \pm 34^{\mathrm{a}} \\
64 \pm 23^{* *} \\
15 \pm 5^{* * *}\end{array}$ \\
\hline
\end{tabular}

flow to this area and the general circulation in the Baltic makes an influence of this coastal water at the open sea station BY31 less likely.

The decrease in the surface layer diatom biomass (the dominant Chaetoceros spp. and the sub-dominant Achnanthes taeniata, Skeletonema costatum, Thalassiosira levanderi), coincided with a decrease in the mixed layer depth during the first 2 wk of April, and depletion of mixed-layer dissolved inorganic nitrogen (DIN) to $10 \mathrm{~m}$ depth. Nitrogen depletion is a common cause of diatom bloom collapse in the Baltic Sea (e.g. von
Table 4. Average daily primary production, daily phytoplankton carbon

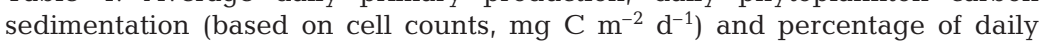
settled primary production $\left(\% \mathrm{~d}^{-1}\right)$. (nd = no data)

\begin{tabular}{|lcrrrrrr|}
\hline Date & $\begin{array}{c}\text { Primary } \\
\text { production } \\
\left(\mathrm{mg} \mathrm{C} \mathrm{m}^{-2} \mathrm{~d}^{-1}\right)\end{array}$ & $\begin{array}{c}\text { Sedimentation of } \\
\text { phytoplankton } \\
\text { carbon } \\
\left(\mathrm{mg} \mathrm{C} \mathrm{m}^{-2} \mathrm{~d}^{-1}\right)\end{array}$ & $\begin{array}{c}\text { Percentage of primary } \\
\text { production settling as } \\
\text { phytoplankton } \\
\text { carbon }\left(\% \mathrm{~d}^{-1}\right)\end{array}$ \\
& $0-25 \mathrm{~m}$ & $25 \mathrm{~m}$ & $50 \mathrm{~m}$ & $100 \mathrm{~m}$ & $25 \mathrm{~m}$ & $50 \mathrm{~m}$ & $100 \mathrm{~m}$ \\
\hline $26 / 03-02 / 04$ & 445 & 9 & 2 & 0.9 & 2 & 0.6 & 0.2 \\
$02 / 04-10 / 04$ & 756 & 27 & 4 & 2 & 4 & 0.5 & 0.2 \\
$10 / 04-16 / 04$ & 949 & 57 & 64 & 2 & 6 & 7 & 0.3 \\
$16 / 04-23 / 04$ & 680 & 164 & 94 & 14 & 24 & 14 & 2 \\
$23 / 04-30 / 04$ & 315 & $\mathrm{nd}$ & 126 & 35 & $\mathrm{nd}$ & 40 & 11 \\
$30 / 04-07 / 05$ & 441 & 155 & 154 & 23 & 35 & 35 & 5 \\
\hline
\end{tabular}

Table 5. Total primary production, sedimentation of phytoplankton carbon (PC, estimated from cell counts and cell volumes) and total settling particulate organic carbon (POC) for the period March 26 to May 7 (in $\mathrm{g} \mathrm{C} \mathrm{m}^{-2}$ period $^{-1}$ ) $\pm 2 \mathrm{SD}$. Percent (\%) of the primary production that settled at different depths is in brackets

\begin{tabular}{|c|c|c|c|c|c|c|c|}
\hline \multirow[t]{2}{*}{ Date } & \multirow{2}{*}{$\begin{array}{c}\text { Primary } \\
\text { production } \\
\left(\mathrm{g} \mathrm{C} \mathrm{m}^{-2} \text { period }^{-1}\right)\end{array}$} & \multicolumn{2}{|c|}{$\begin{array}{l}\text { Sedimentation } 25 \mathrm{~m} \\
\left(\mathrm{~g} \mathrm{C} \mathrm{m}^{-2} \text { period }^{-1}\right)\end{array}$} & \multicolumn{2}{|c|}{$\begin{array}{l}\text { Sedimentation } 50 \mathrm{~m} \\
\left(\mathrm{~g} \mathrm{C} \mathrm{m}^{-2} \text { period }^{-1}\right)\end{array}$} & \multicolumn{2}{|c|}{$\begin{array}{l}\text { Sedimentation } 100 \mathrm{~m} \\
\quad\left(\mathrm{~g} \mathrm{C} \mathrm{m}^{-2} \text { period }^{-1}\right)\end{array}$} \\
\hline & & $\mathrm{PC}$ & POC & PC & POC & $\mathrm{PC}$ & POC \\
\hline $26 / 03-07 / 05$ & 24.9 & $\begin{array}{c}4.0 \pm 1.2^{\mathrm{a}} \\
\quad(16)\end{array}$ & $\begin{array}{l}3.0 \pm 0.6 \\
(12)\end{array}$ & $\begin{array}{l}3.0 \pm 0.9 \\
(12)\end{array}$ & $\begin{array}{l}3.0 \pm 0.5 \\
(12)\end{array}$ & $\begin{array}{l}0.5 \pm 0.2 \\
(2)\end{array}$ & $\begin{array}{l}3.1 \pm 0.6 \\
\quad(12)\end{array}$ \\
\hline
\end{tabular}


Bodungen et al. 1981, Larsson et al. 1986b, Kuuppo et al. 1998). Silica deficiency can also cause the decline of diatom blooms (Bienfang et al. 1982), but was obviously not the cause here, since there was still plenty of silica left in the water column. In contrast to other diatoms, the large-celled $T$. baltica persisted in low abundance throughout the study despite continuous settling losses, suggesting a slow, steady growth in the nitrogen- deficient mixed layer possibly sustained by internally stored nutrients.

A shift from a dominance of diatoms to dinoflagellates during the spring bloom is commonly seen in the investigated area (Larsson \& Hajdu 1997, Hajdu 2002), as well as in other parts of the Baltic Sea proper (e.g. Niemi 1973, Kononen \& Niemi 1984, Niemi \& Åström 1987, Heiskanen \& Kononen 1994, Wasmund et al. 1998). Our data indicate that the early shift from nonswimming diatoms to swimming dinoflagellates resulted from the establishment of a shallow mixed layer that limited the fraction of the winter-storage of inorganic nitrogen available to the diatoms and enhanced their sedimentation out of the photic zone. This suggests that the dominance of diatoms in spring is climatically controlled and determined by the balance between the spreading of juvenile freshwater (Eilola \& Stigebrandt 1998), which stabilise the water column, and wind-forced mixing.

Scrippsiella hangoei became abundant when DIN was depleted in the surface mixed layer and then continued to increase its biomass and vertical distribution concomitant to an extension of the nitrogendepleted layer to $30 \mathrm{~m}$ depth. Olli et al. (1998) considered $S$. hangoei to be non-migratory and a resident of the nutrient-depleted mixed layer. Our data, however, suggest migration for nutrients to sub-pycnocline waters to sustain the observed increase in biomass. It is not possible to determine to what extent actively migrating cells were responsible for the observed distribution to $40 \mathrm{~m}$ depth in late April, but estimates of potential migration amplitudes for similar sized dinoflagellates (Sommer 1988) suggest a substantial contribution from settling cells. A substantial settling is also indicated by the drastic decline of $S$. hangoei a week after the peak. Nutrients at below 30 $\mathrm{m}$ decreased further when Peridiniella catenata, known to migrate vertically (Passow 1991b, Heiskanen 1995), also built up a substantial biomass and helped to consume most of the DIN down to $40 \mathrm{~m}$ depth. The dominance of $P$. catenata late in the bloom suggests they out-compete $S$. hangoei by migrating deeper, since DIN was depleted almost down to $50 \mathrm{~m}$ depth. This is consistent with the observation that species (e.g. P. catenata) that form cell chains swim faster than single-celled species (Fraga et al. 1989).

\section{Selective sedimentation}

Differences in species composition between the water column and the sediment traps indicate large between-species variability in settling. Waite et al. (1992b) found similar differences in settling of the genera Thalassiosira and Chaetoceros in Auke Bay (Alaska), with higher sedimentation loss rates of Thalassiosira than of Chaetoceros species. Thalassiosira species are nutrient-sensitive (Waite et al. 1992a) and seem to need high nutrient concentrations to sustain rapid growth, to compensate for their high settling rate. T. levanderi, with a high growth rate at the beginning of the bloom as well as a high sedimentation rate, disappeared quickly from the water column once nitrogen was depleted in the mixed layer, as has regularly been observed in the area (S. Hajdu, unpubl. data) and also reported by Passow (1991a). Mucus produced by senescent cells (e.g. T. levanderi), can induce aggregate formation and greatly increase the settling rate of diatoms (Smetacek 1985). To the extent that aggregate formation occurred, in this case it seemed to be a selective process which did not remove species from the water column. Much of the large-celled T. baltica population was found at deeper depths late in the bloom, indicating settlement as intact cells. Thick cells walls and rapid settling presumably prevented this species from disintegrating in the water column while settling. The slow settling of delicate Chaetoceros cells may be due to their long hair-like spines, which increase friction and lower sinking rates (Smayda \& Boleyn 1966, Brönmark \& Hansson 1998). Disintegration of the delicate cells might be another explanation for their low recovery in the sediment traps.

Dinoflagellates have also been found to disintegrate in the water column (Heiskanen \& Kononen 1994) and hence, their vegetative cells are seldom found in sediment traps. The colony forming Peridiniella catenata was, however, found in the 25 and $50 \mathrm{~m}$ sediment traps in about the same proportions as in the water column (Table 1). P. catenata is a vertically migrating species (Passow 1991b, Olli et al. 1998) and has been found to actively swim into sediment traps, which may bias the measurements, especially when preservatives are used (Heiskanen 1995). Passow (1991b) found P. catenata to migrate to at least $30 \mathrm{~m}$ depth, but our water column data indicate they may actually migrate to $50 \mathrm{~m}$ depth. We used a preservative (chloroform) and our settling rates of $P$. catenata may be biased by vertically migrating cells. Since $P$. catenata constituted the bulk of settling cells above the halocline, PC and POC settling rates also may therefore be overestimated. Below $50 \mathrm{~m}$ and in the $100 \mathrm{~m}$ trap we found very few P. catenata indicating a very low settling rate or high loss through disintegration or grazing in the halocline layer. 
The other dominant dinoflagellate, Scrippsiella hangoei, was very abundant in the surface layer, but rare in the sediment traps. S. hangoei has very thin and delicate plates (Larsen et al. 1995) and is sensitive to preservatives such as formaldehyde, which cause deformation and dissolution of the cells (Heiskanen 1995). If chloroform has a similar effect, this could explain a low recovery in the traps. S. hangoei is reported to form resting cysts that settle rapidly (Heiskanen 1993), but we found no cysts in the sediment traps or in the water column. Cyst formation can be preceded by planozygotes, large cells with a diameter $>22 \mu \mathrm{m}$ according to Kremp \& Heiskanen (1999). We found these larger cells throughout the bloom, but they were scarce $(<10 \%$ of total abundance) and we found no mass production of planozygotes. Cell size remained at a mean diameter of 18 to $19 \mu \mathrm{m}$ throughout the bloom.

\section{Phytoplankton carbon and total particulate organic carbon (POC) in settling material}

Early in the bloom, particulate organic carbon (POC) and phytoplankton carbon (PC) were not statistically different in shallow traps indicating almost all carbon settled as intact cells. On 1 occasion, estimated PC clearly exceeded POC in material collected at $50 \mathrm{~m}$ depth. Differences in exposure time and losses due to the preservative used (cf. Kähler \& Bauerfeind 2001) may have reduced the carbon content of the settled POC due to longer exposure time ( 2 wk compared to $1 \mathrm{wk})$. Over-estimation of PC when converting cell volumes to carbon might be another explanation for the discrepancies between PC and POC.

POC settling rates were very similar at all trap depths when summed over the bloom period (3.0 to $3.1 \mathrm{~g} \mathrm{C} \mathrm{m}^{-2}$, March 26 to May 7, Table 5) and were only $12 \%$ of measured phytoplankton primary production $\left(24.9 \mathrm{~g} \mathrm{C} \mathrm{m}^{-2}\right)$. Contrary to POC, the fraction of recognisable cells decreased with depth, particularly from 50 to $100 \mathrm{~m}$, as did the number of cells in the water mass. This suggests that diatoms as well as dinoflagellates are rapidly degraded and will settle as unrecognisable detritus or not at all. This is well known for dinoflagellates (Heiskanen \& Kononen 1994), but diatoms are generally considered to settle as intact cells (Davies \& Payne 1984). During the bloom (March 26 to May 7), only $18 \%$ of the POC settled in the $100 \mathrm{~m}$ trap could be attributed to recognisable phytoplankton, of which $87 \%$ was diatoms.

Predation by mesozooplankton is commonly considered of minor importance in spring due to the low zooplankton abundance (Larsson et al. 1986b), although migrating zooplankton may alter the collected material in the trap, if no preservative is used (Lee et al. 1992). The open Baltic Sea proper has an over-wintering population of Pseudocalanus in the deep water, if the water carries sufficient oxygen, even below the permanent halocline (E. Gorokhova pers. comm.) (Ackefors 1969). They start to reproduce in spring and their grazing might explain some of the loss of cells from 50 to $100 \mathrm{~m}$ depth. Microzooplankton may also consume a significant fraction of spring phytoplankton in the Baltic proper (Johansson et al. 2004).

\section{Concluding remarks}

Our estimated export production is lower than generally reported from coastal waters (e.g. Larsson et al. 1986b, Wassmann 1991, Heiskanen \& Leppänen 1995) and suggests that extrapolation from coastal studies may overestimate offshore settling rates. Furthermore, our estimates of settling rates at 25 and $50 \mathrm{~m}$ depth were likely biased by trapped vertically migrating dinoflagellates. This bias is counteracted by a likely under-trapping (Gustafsson et al. 2004) and consequently, the absolute magnitude of export production is uncertain.

It is not clear why settling of recognisable cells decreased sharply below $50 \mathrm{~m}$ depth, as indicated by cell numbers in the water mass and in traps, but disintegration due to lowered settling rates in the pycnoline and grazing from deep over-wintering zooplankton populations likely contributed.

The low sedimentation of identifiable cells below the halocline and the species-specific sedimentation patterns may complicate the interpretation of paleoecological studies of sedimentary records since settling species composition at depth will not accurately mirror the true surface phytoplankton community.

It is commonly assumed that silica availability determines the dominance of diatoms in spring, but our data indicate that climate factors determining the mixed layer depth, and consequently the amount of nutrients available to non-swimming diatoms, may initiate a decline in diatoms and succession to dinoflagellates even while significant amounts of silica are still present.

Acknowledgements. We thank V. Lindblom for counting the phytoplankton cells in the water and sediment trap samples. We are also grateful to B. Abrahamsson, L. Lundgren and J. Walve for help taking the samples, and to A. Sjösten and the staff at the Chemical Analysis laboratory at our department for chemical analysis. We thank J. O. Persson (Mathematical statistics, Stockholm University) for kindly helping us with the statistics, R. Elmgren for linguistic corrections and T. Hama and 3 anonymous reviewers for valuable comments on the manuscript. Funding was given by the EU through BASYS within the MAST III program (MAS3-CT96-0058), the 
Swedish Foundation for strategic Environmental Research (MISTRA: SUCOZOMA) and the Swedish EPA which also provided data collected within the Swedish Marine Monitoring Program.

\section{LITERATURE CITED}

Ackefors H (1969) Ecological zooplankton investigations in the Baltic proper 1963-1965. Inst Mar Res Lysekil Ser Biol Rep 18:1-139

Bienfang PK, Harrison PJ, Quarmby LM (1982) Sinking rate response to depletion of nitrate, phosphate and silicate in four marine diatoms. Mar Biol 67:295-302

Bloesch J, Burns N (1980) A critical review of sedimentation trap technique. Schweiz Z Hydrol 42:15-55

Blomqvist S, Håkansson L (1981) A review on sediment traps in aquatic environments. Arch Hydrobiol 91:101-132

Blomqvist S, Heiskanen AS (2001) The challenge of sedimentation in the Baltic Sea. In: Wulff FV, Rahm LA, Larsson P (eds) A systems analysis of the Baltic Sea. Ecological studies, Vol. 148. Springer-Verlag, Heidelberg, p 211-227

Blomqvist S, Larsson U (1994) Detrital bedrock elements as tracers of settling resuspended particulate matter in a coastal area of the Baltic Sea. Limnol Oceanogr 39: 880-896

Brönmark C, Hansson LA (1998) The biology of lakes and ponds. In: Crawley M, Little C, Southwood TRE, Ulfstrand $\mathrm{S}$ (eds) Biology of habitats. Oxford University Press, Oxford

Davies JM, Payne R (1984) Supply of organic matter to the sediment in the northern North Sea during a spring phytoplankton bloom. Mar Biol 78:315-324

Edler L (1979) Recommendations on methods for marine biological studies in the Baltic Sea. Phytoplankton and chlorophyll. The Baltic Marine Biologists Publ 5:1-38

Eilola K (1997) Development of a spring thermocline at temperatures below the temperature of maximum density, with application to the Baltic Sea. J Geophys Res 102: 8657-8662

Eilola K, Stigebrandt A (1998) Spreading of juvenile freshwater in the Baltic proper. J Geophys Res C Oceans 103: $27795-27807$

Elmgren R (1978) Structure and dynamics of Baltic benthos communities, with particular reference to the relationship between macro- and meiofauna. Kieler Meeresforsch Sonderh 4:1-22

Forsskåhl M, Laakonen A, Leppänen JM, Niemi Å, Sundberg A, Tamelander G (1982) Seasonal cycle of production and sedimentation of organic matter at the entrance to the Gulf of Finland. Neth J Sea Res 16:290-299

Fraga S, Gallager SM, Anderson DM (1989) Chain-forming dinoflagellates: An adaptation to red-tides. In: Okaichi T, Anderson DM, Nemoto T (eds) Red tides: biology, environmental science, and toxicology. Elsevier, New York, p 281-284

Gardner WD (1980) Field assessment of sediment traps. J Mar Res 38:41-52

Gustafsson Ö, Andersson P, Roos P, Kukulska Z, Broman D, Larsson U, Hajdu S, Ingri J (2004) Evaluation of the collection efficiency of upper ocean sub-photic-layer sediment traps: a 24-month in situ calibration in the open Baltic Sea using ${ }^{234}$ Th. Limnol Oceanogr: Methods 2:62-74

Haecky P, Jonsson S, Andersson A (1998) Influence of sea ice on the composition of the spring phytoplankton bloom in the northern Baltic Sea. Polar Biol 20:1-8

Hajdu S (2002) Phytoplankton of Baltic environmental gradi- ents: observations on potentially toxic species. $\mathrm{PhD}$ thesis, University of Stockholm

Hargrave BT, Burns NM (1979) Assessment of sediment trap collection efficiency. Limnol Oceanogr 24:1124-1136

Heiskanen AS (1993) Mass encystment and sinking of dinoflagellates during a spring bloom. Mar Biol 116: $161-167$

Heiskanen AS (1995) Contamination of sediment trap fluxes by vertically migrating phototrophic micro-organisms in the coastal Baltic Sea. Mar Ecol Prog Ser 122:45-58

Heiskanen AS (1998) Factors governing sedimentation and pelagic nutrient cycles in the northern Baltic Sea. Monogr Boreal Environ Res 8:1-80

Heiskanen AS, Kononen K (1994) Sedimentation of vernal and late summer phytoplankton communities in the coastal Baltic Sea. Arch Hydrobiol 131:175-198

Heiskanen AS, Leppänen JM (1995) Estimation of export production in the coastal Baltic Sea: effect of resuspension and microbial decomposition on sedimentation measurements. Hydrobiologia 316:211-224

HELCOM (1988) Guidelines for the Baltic monitoring programme for the third stage. Part D. Biological determinants. Baltic Sea Environment Proceedings No 27D. Helsinki Commission, Helsinki

Horn H, Horn W (1993) Sedimentary losses in the reservoir Saidenbach: flux and sinking velocities of dominant phytoplankton species. Int Rev Gesamten Hydrobiol 78:39-57

Jeffrey SW, Humphrey GF (1975) New spectrophotometric equations for determining chlorophyll $a, b, c-1$ and $c-2$ in higher plants, algae and natural phytoplankton. Biochem Physiol Planzen 167:191-194

Johansson M, Gorokhova E, Larsson U (2004) Annual variability in ciliate community structure, potential prey and predators in the open northern Baltic Sea proper. J Plankton Res 26:67-80

Kähler P, Bauerfeind E (2001) Organic particles in a shallow sediment trap: Substantial loss to the dissolved phase. Limnol Oceanogr 46:719-723

Kaiser W, Schulz S (1978) On the causes for the differences in space and time of the commencement of the phytoplankton bloom in the Baltic. Kieler Meeresforsch 4:161-170

Kahru M, Nômmann S (1990) The phytoplankton spring bloom in the Baltic Sea in 1985, 1986: multitude of spatiotemporal scales. Cont Shelf Res 10:329-354

Kononen K, Niemi Å (1984) Long-term variation of the phytoplankton composition at the entrance to the Gulf of Finland. Ophelia Suppl 3:101-110

Kremp A, Heiskanen AS (1999) Sexuality and cyst formation of the spring-bloom dinoflagellate Scrippsiella hangoei in the coastal northern Baltic Sea. Mar Biol 134:771-777

Kuparinen J, Leppänen JM, Sarvala J, Sundberg A, Virtanen A (1984) Production and utilization of organic matter in a Baltic ecosystem off Tvärminne, southwest coast of Finland. Rapp P-V Reun Cons Int Explor Mer 183:180-192

Kuuppo P, Autio R, Kuosa H, Setälä O, Tanskanen S (1998) Nitrogen, silicate and zooplankton control of the planktonic food-web in spring. Estuar Coast Shelf Sci 46:65-75

Larsen J, Kuosa H, Ikävalko J, Kivi K, Hällfors S (1995) A redescription of Scrippsiella hangoei (Schiller) comb. nov. - a 'red tide' dinoflagellate from the northern Baltic. Phycologia 34:135-144

Larsson U, Hajdu S (1997) The high frequency monitoring. In: Tidlund A (ed) Baltic 96. Stockholm Marine Research Centre, Stockholm, p 28-31 (In Swedish)

Larsson U, Blomqvist S, Abrahamsson B (1986a) A new sediment trap system. Mar Ecol Prog Ser 31:205-207

Larsson U, Hobro R, Wulff F (1986b) Dynamics of a phyto- 
plankton spring bloom in a coastal area of the northern Baltic proper. Contrib Askö Lab Univ Stockholm 30:1-32

Lee C, Hedges JI, Wakeham SG, Zhu N (1992) Effectiveness of various treatments in retarding microbial activity in sediment trap material and their effects on the collection of swimmers. Limnol Oceanogr 37:117-130

Lehtonen K, Andersin AB (1998) Population dynamics, response to sedimentation and role in benthic metabolism of the amphipod Monoporeia affinis in an open-sea area of the northern Baltic Sea. Mar Ecol Prog Ser 168:71-85

Leppänen JM (1988) Cycling of organic matter during the vernal growth period in the open northern Baltic proper. VI. Sinking of particulate matter. Finn Mar Res 255:97-118

Leppänen JM, Kononen K (1988) Cycling of organic matter during the vernal growth period in the open northern Baltic proper. III. Phytoplankton composition and estimation of loss rates of phytoplankton production. Finn Mar Res 255:37-54

Lund JWG, Kipling C, Le Cren ED (1958) The inverted microscope method of estimating algal numbers and the statistical basis of estimations by counting. Hydrobiologia 11: $143-170$

Menden-Deuer S, Lessard EJ (2000) Carbon to volume relationships for dinoflagellates, diatoms and other protist plankton. Limnol Oceanogr 45:569-579

Niemi Å (1973) Ecology of phytoplankton in the Tvärminne area SW coast of Finland. I. Dynamics of hydrography, nutrients, chlorophyll $a$ and phytoplankton. Acta Bot Fenn 100:1-68

Niemi Å, Åström AM (1987) Ecology of phytoplankton in the Tvärminne area, SW coast of Finland. IV: Environmental conditions, chlorophyll $a$ and phytoplankton in winter and spring 1984 at Tvärminne Storfjärd. Ann Bot Fenn 24: 333-352

Ólafsson E, Elmgren R (1997) Seasonal dynamics of sublittoral meiobenthos in relation to phytoplankton sedimentation in the Baltic Sea. Estuar Coast Shelf Sci 45:149-164

Olli K, Heiskanen AS (1999) Seasonal stages of phytoplankton community structure and sinking loss in the Gulf of Riga. J Mar Syst 23:165-184

Olli K, Heiskanen AS, Lohikari K (1998) Vertical migration of autotrophic micro-organisms during a vernal bloom at the coastal Baltic Sea - coexistence through niche separation. Hydrobiologia 363:179-189

Öström B (1974) An algorithm for the computation of primay production. Bot Mar 17:20-22

Passow U (1991a) Species-specific sedimentation and sinking velocities of diatoms. Mar Biol 108:449-455

Passow U (1991b) Vertical migration of Gonyaulax catenata and Mesodinium rubrum. Mar Biol 110:455-463

Peinert R, von Bodungen B, Smetacek VS (1989) Food web structure and loss rate. In: Berger $\mathrm{WH}$, Smetacek VS, Wefer G (eds) Productivity of the ocean: past and present. John Wiley \& Sons, Chicester, p 35-48

Rahm L (1987) Oxygen consumption in the Baltic proper. Limnol Oceanogr 32:973-978

Reynolds CS, Wiseman SW (1982) Sinking losses of phytoplankton in closed limnetic systems. J Plankton Res 4: 489-522

Rice JA (1993) Mathematical statistics and data analysis. Duxbury Press, Belmont, CA

Editorial responsibility: Otto Kinne (Editor), Oldendorf/Luhe, Germany
Riebesell U (1989) Comparison of sinking and sedimentation rate measurements in a diatom winter/spring bloom. Mar Ecol Prog Ser 54:109-119

Smayda TJ, Boleyn BJ (1966) Experimental observations on the flotation of marine diatoms. III. Bacteriastrum hyalinum and Chaetoceros lauderi. Limnol Oceanogr 11: $35-43$

Smetacek V (1980) Annual cycle of sedimentation in relation to plankton ecology in western Kiel bight. Ophelia Suppl 1:65-76

Smetacek V (1985) Role of sinking in diatom life-history cycles: ecological, evolutionary and geological significance. Mar Biol 84:239-251

Smetacek V, von Bröckel K, Zeitzschel B, Zenk W (1978) Sedimentation of particulate matter during a phytoplankton spring bloom in relation to the hydrographical regime. Mar Biol 47:211-226

Smetacek V, Passow U (1990) Spring bloom initiation and Svedrup's critical-depth model. Limnol Oceanogr 35: $228-234$

Sommer U (1988) Some size relationships in phytoplankton motility. Hydrobiologia 161:125-131

Stigebrandt A (1991) Computations of oxygen fluxes through the sea surface and the net production of organic matter with application to the Baltic and adjacent seas. Limnol Oceanogr 36:444-454

Stigebrandt A (2001) Physical oceanography of the Baltic Sea. In: Wulff F, Rahm L, Larsson P (eds) A system analysis of the Baltic Sea. Ecological Studies Vol 148. SpringerVerlag, Heidelberg, p 19-74

Struck U, Pollehne F, Bauerfeind E, von Bodungen B (2004) Sources of nitrogen for the vertical particle flux in the Gotland Sea (Baltic Proper) - results from sediment trap studies. J Mar Syst 45:91-101

Tallberg P, Heiskanen AS (1998) Species-specific phytoplankton sedimentation in relation to primary production along an inshore-offshore gradient in the Baltic Sea. J Plankton Res 20:2053-2070

Venrick EL (1978) How many cells to count? In: Sournia A (ed) Phytoplankton manual. monographs on oceanographic methodology 6. UNESCO, Paris, p 167-180

von Bodungen B, von Bröckel K, Smetacek V, Zeitzschel B (1981) Growth and sedimentation of the phytoplankton spring bloom in the Bornholm Sea (Baltic Sea). Kieler Meeresforsch Sonderh 5:49-60

Waite A, Bienfang PK, Harrison PJ (1992a) Spring bloom sedimentation in a subarctic ecosystem. I. Nutrient sensitivity. Mar Biol 114:119-129

Waite A, Bienfang PK, Harrison PJ (1992b) Spring bloom sedimentation in a subarctic ecosystem. II. Succession and sedimentation. Mar Biol 114:131-138

Wasmund N, Nausch G, Matthäus W (1998) Phytoplankton spring blooms in the southern Baltic Sea-spatiotemporal development and long-term trends. J Plankton Res 20:1099-1117

Wassmann P (1991) Dynamics of primary production and sedimentation in shallow fjords and polls of western Norway. Oceanogr Mar Biol Annu Rev 29:87-154

Wassmann P (1998) Retention versus export food chains: processes controlling sinking loss from marine pelagic systems. Hydrobiologia 363:29-57

Submitted: June 20, 2003; Accepted: July 22, 2004

Proofs received from author(s): November 18, 2004 